\title{
Isolation of T-mycoplasmas from Dogs and Squirrel Monkeys: Biological and Serological Comparison with those Isolated from Man and Cattle
}

\author{
By D. TAYLOR-ROBINSON,* C. MARTIN-BOURGON, \\ T. WATANABE AND J. P. ADDEY \\ M.R.C. Clinical Research Centre, Harvard Hospital, Salisbury, Wiltshire
}

(Accepted for publication I July I97I)

\begin{abstract}
SUMMARY
Mycoplasmas which metabolized urea and produced small colonies on agar medium were isolated from the genital tracts of dogs and from the throats of squirrel monkeys. Attempts to isolate similar organisms from baboons, cats, horses, pigs and rabbits were not successful. The biological and physical properties of the mycoplasmas isolated from dogs and monkeys were closely similar to those of T-mycoplasmas isolated previously from man and cattle, so that the canine and simian strains could be regarded undoubtedly as members of the T-mycoplasma group. The metabolic-inhibition technique was used to show that the T-mycoplasmas of the four 'host' species were not related to known large colony-forming mycoplasmas of these species. The same technique revealed that some of the Tmycoplasma strains isolated from a particular species were different from one another, except the simian strains which appeared to be the same as each other. In addition, the results of tests with a single or a few strains isolated from each of the four species showed that the strains of one species were not serologically related to those of another. On the other hand, polyacrylamide gel electrophoresis studies, in which at least II lines were observed with T-mycoplasma antigens, indicated that the structural proteins of strains isolated from the various species were closely similar. The fact that all the strains examined could be regarded as belonging to one closely related group is discussed in the context of the eventual nomenclature for these organisms.
\end{abstract}

\section{INTRODUCTION}

T-mycoplasmas were isolated first by Shepard (I954) from material obtained from the human urogenital tract. Since that time there have been numerous reports (see TaylorRobinson, Addey, Hare \& Dunlop, 1969) of their isolation from the genital tract of man in studies often concerned with whether or not these mycoplasmas cause non-specific urethritis; they have also been isolated from the human oropharynx (Taylor-Robinson \& Purcell, 1966; Ford, 1967; Purcell et al. 1967). In addition, T-mycoplasmas have been isolated from the urogenital tract of cattle (Taylor-Robinson, Haig \& Williams, 1967; Taylor-Robinson, Williams \& Haig, I968; Taylor-Robinson, Thomas \& Dawson, I969) and also from the respiratory tract of these animals (Gourlay, 1968). This communication describes their isolation from dogs and squirrel monkeys and efforts to isolate them from some other mammalian species. The strains from various species are shown to be similar biologically and structurally, indicating that the T-mycoplasmas form a well-defined group, although it is possible to differentiate the strains using serological techniques.

\footnotetext{
* Present address: Clinical Research Centre, Watford Road, Harrow, Middlesex HAI 3 UJ.
} 


\section{METHODS}

Mycoplasmas. T-mycoplasmas, designated REOW and T354, both isolated from the human genital tract, were supplied by Professor R. E. O. Williams and Dr R. H. Purcell, respectively. A T-mycoplasma, designated 'JOHNSON' was isolated in this laboratory from the human oropharynx (Taylor-Robinson \& Purcell, 1966). T-mycoplasmas U 8, U I4 and U 20 were isolated from the genital tract of cattle as described previously (Taylor-Robinson, Williams \& Haig, I968). The source of classical large colony-forming mycoplasmas used for comparative purposes was described elsewhere (Manchee \& Taylor-Robinson, I968).

Media. Liquid medium for the isolation and growth of T-mycoplasmas consisted of Difco PPLO broth (70 ml.), $25 \%$ (w/v) aqueous extract of Distillers Co. Ltd dried yeast (IO ml.), unheated Burroughs Wellcome horse serum no. 6 (20 ml.), $0.1 \%$ urea and $0.002 \%$ phenol red; thallium acetate $(\mathrm{I}: 4000)$ and penicillin ( $1000 \mathrm{units} / \mathrm{ml}$.) were included in all batches of medium. The medium was adjusted with $0 . \mathrm{I} \mathrm{N}-\mathrm{HCl}$ to $\mathrm{pH} 6.5$ or less for isolation of $\mathrm{T}$ mycoplasmas and to $\mathrm{pH} 7.0$ for metabolic-inhibition tests. Solid medium contained in addition I \% Oxoid Ionagar no. 2. Some batches of solid medium also contained $0.05 \mathrm{M}-\mathrm{N}-2-$ hydroxyethylpiperazine- $N^{\prime}$-2-ethanesulphonic acid (HEPES) buffer (Manchee \& TaylorRobinson, $1969 a$ ). Large colony-forming mycoplasmas were grown in the medium described above but with the urea replaced by either $0.1 \%$ arginine or $0.1 \%$ glucose.

Isolation and titration of viable organisms. T-mycoplasmas were isolated as described by Taylor-Robinson, Williams \& Haig (1968). Suspensions of mycoplasmas were titrated to estimate the number of organisms by making serial tenfold dilutions in medium in screwcapped vials. Growth of the T-mycoplasmas and those mycoplasmas which metabolized arginine produced a colour change in the medium from yellow $(\mathrm{pH} \mathrm{6.5)}$ ) to pink ( $\mathrm{pH} 8.0$ or above); those mycoplasmas which metabolized glucose produced a colour change from pink ( $\mathrm{pH} 7.8$ ) to yellow ( $\mathrm{pH} 6.5$ or below). Medium was incubated at $36^{\circ}$ until colour changes were complete. One colour-changing unit (c.c.u.) of activity was defined as the highest dilution of the mycoplasma suspension which produced a colour change. Sometimes solid medium was inoculated with samples of the suspensions, and colonies counted after incubation at $36^{\circ}$ in an atmosphere of $95 \% \mathrm{~N}_{2}+5 \% \mathrm{CO}_{2}$.

Ammonia estimation. Ammonia was converted to ammonium borate and then titrated (Manchee \& Taylor-Robinson, 1969a).

Cell adsorption tests. Tests for adsorption of erythrocytes from dogs, squirrel monkeys, cattle, men and chickens to colonies were performed as described by Manchee \& TaylorRobinson (1968), and tests for adsorption of HeLa cells as described by Manchee \& TaylorRobinson (1969 $b$ ).

Antibiotic sensitivity tests. The inhibitory effect of various antibiotics (penicillin, erythromycin and demethylchlortetracycline (Ledermycin) on the growth of mycoplasmas in liquid medium was measured by a microtechnique (Taylor-Robinson, 1967).

Other tests. The effects of ether, freezing and thawing, and freeze-drying, on the stability of the mycoplasmas were tested as described previously (Taylor-Robinson, Williams \& Haig, 1968). Likewise, Gradocol and Millipore membrane filtrations were done as described before (Taylor-Robinson, Williams \& Haig, 1968).

Metabolic-inhibition (m.i.) test. The inhibitory effect of rabbit antisera on T-mycoplasmas was measured by the technique described by Purcell, Taylor-Robinson, Wong \& Chanock (1966). Antisera were prepared as described previously (Taylor-Robinson, Somerson, Turner \& Chanock, 1963) except that the organisms were grown in the media described above and not in medium containing rabbit serum. 
Polyacrylamide gel electrophoresis. Each T-mycoplasma was grown in I 1. of medium for $48 \mathrm{~h}$. at $36^{\circ}$. The organisms were harvested at $35,000 \mathrm{~g}$ for $30 \mathrm{~min}$. and washed three times in $40 \mathrm{ml}$. of $0.25 \mathrm{M}-\mathrm{NaCl}$ and suspended in $2 \mathrm{ml}$. of the same solution. The amount of protein in the suspension was determined by the technique of Lowry, Rosebrough, Farr \& Randall (195I). The gel electrophoresis technique described by Razin \& Rottem (I967) was followed. Glass tubes, measuring $5 \mathrm{~mm} . \times 75 \mathrm{~mm}$., were used. Polymerization was carried out at $37^{\circ}$ for $60 \mathrm{~min}$. Electrophoresis was done at room temperature with a current of $2 \mathrm{~mA}$./tube for $5 \mathrm{~min}$. and then $5 \mathrm{~mA}$./tube for $3 \mathrm{~h}$. The gels were stained for $\mathrm{I} \mathrm{h}$. with $0.5 \%$ Coomassie Brilliant Blue in $9 \%(\mathrm{v} / \mathrm{v})$ acetic acid and $40 \%(\mathrm{w} / \mathrm{v})$ methanol. They were destained overnight in the same acetic acid-methanol mixture, changed to $9 \%$ acetic acidIo $\%$ methanol for 24 to $48 \mathrm{~h}$. and stored in $9 \%(\mathrm{v} / \mathrm{v})$ acetic acid.

Table I. Investigation of various adult animal species for presence of T-mycoplasmas

\begin{tabular}{|c|c|c|c|}
\hline Species & Site tested & No. tested & No. positive \\
\hline Dog & $\left.\begin{array}{l}\text { Throat } \\
\text { Urethra } \\
\text { Semen } \\
\text { Urethra } \\
\text { Semen } \\
\text { Vagina }\end{array}\right\}$ & $\begin{array}{r}I \\
2 \\
13\end{array}$ & 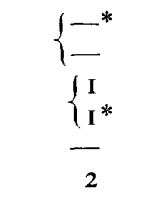 \\
\hline Monkey (squirrel) & Throat & 5 & 5 \\
\hline Baboon & $\left.\begin{array}{l}\text { Mouth } \\
\text { Cervix } \\
\text { Syn. fluid }\end{array}\right\}$ & $\begin{array}{l}4 \\
\text { I }\end{array}$ & - \\
\hline Cat (domestic) & Vagina & 17 & - \\
\hline Horse & $\begin{array}{l}\text { Nose } \\
\text { Vagina }\end{array}$ & $\begin{array}{l}4 \\
2\end{array}$ & - \\
\hline Pig & $\begin{array}{l}\text { Lung } \\
\text { Preputial sac } \\
\text { Preputial sac of neutered animals } \\
\text { Vagina }\end{array}$ & $\begin{array}{l}\text { I } \\
\text { I } \\
4 \\
2\end{array}$ & $\begin{array}{l}- \\
- \\
-\end{array}$ \\
\hline Rabbit & $\left.\begin{array}{l}\text { Nose } \\
\text { Throat } \\
\text { Vagina }\end{array}\right\}$ & $\begin{array}{r}24 \\
8\end{array}$ & - \\
\hline
\end{tabular}

\section{RESULTS}

\section{Isolation of T-mycoplasmas from dogs and squirrel monkeys}

Vaginal swabs from 13 bitches, and preputial swabs from two dogs, including seminal fluid from one of them, were examined (Table I). T-mycoplasmas were isolated from the vagina of two of the bitches, and from a dog. In the case of the latter, the preputial swab contained $10^{6}$ or more organisms and the seminal fluid $10^{5}$ or more organisms per $\mathrm{ml}$. Throat swabs from five squirrel monkeys were examined and all of these yielded T-mycoplasmas.

Attempts to isolate T-mycoplasmas from other species. The details of various unsuccessful attempts to isolate from specimens obtained from a variety of sources are shown in Table I. It is noteworthy that specimens from the preputial sac of pigs caused colour changes to occur in the urea-containing medium within a few hours of inoculation. However, such 
rapid colour changes were not associated with the growth of T-mycoplasmas; colour changes did not develop on subculture, nor were colonies of mycoplasmas observed on agar medium.

\section{Biological and physical characteristics of canine and simian T-mycoplasmas}

Properties similar to those of human and bovine strains. These properties are shown in Table 2 and they are compared with those of a typical large colony-forming mycoplasma, namely Mycoplasma hominis. On solid medium the colonies of T-mycoplasmas were small in diameter, those of the canine strain being largest. The addition of $0.05 \mathrm{M}$-HEPES buffer to the agar medium produced colonies which were much greater in diameter; this enhancement of colony size has been described previously (Manchee \& Taylor-Robinson, I969a). Growth of the various strains in liquid media without HEPES buffer is shown in Fig. I.

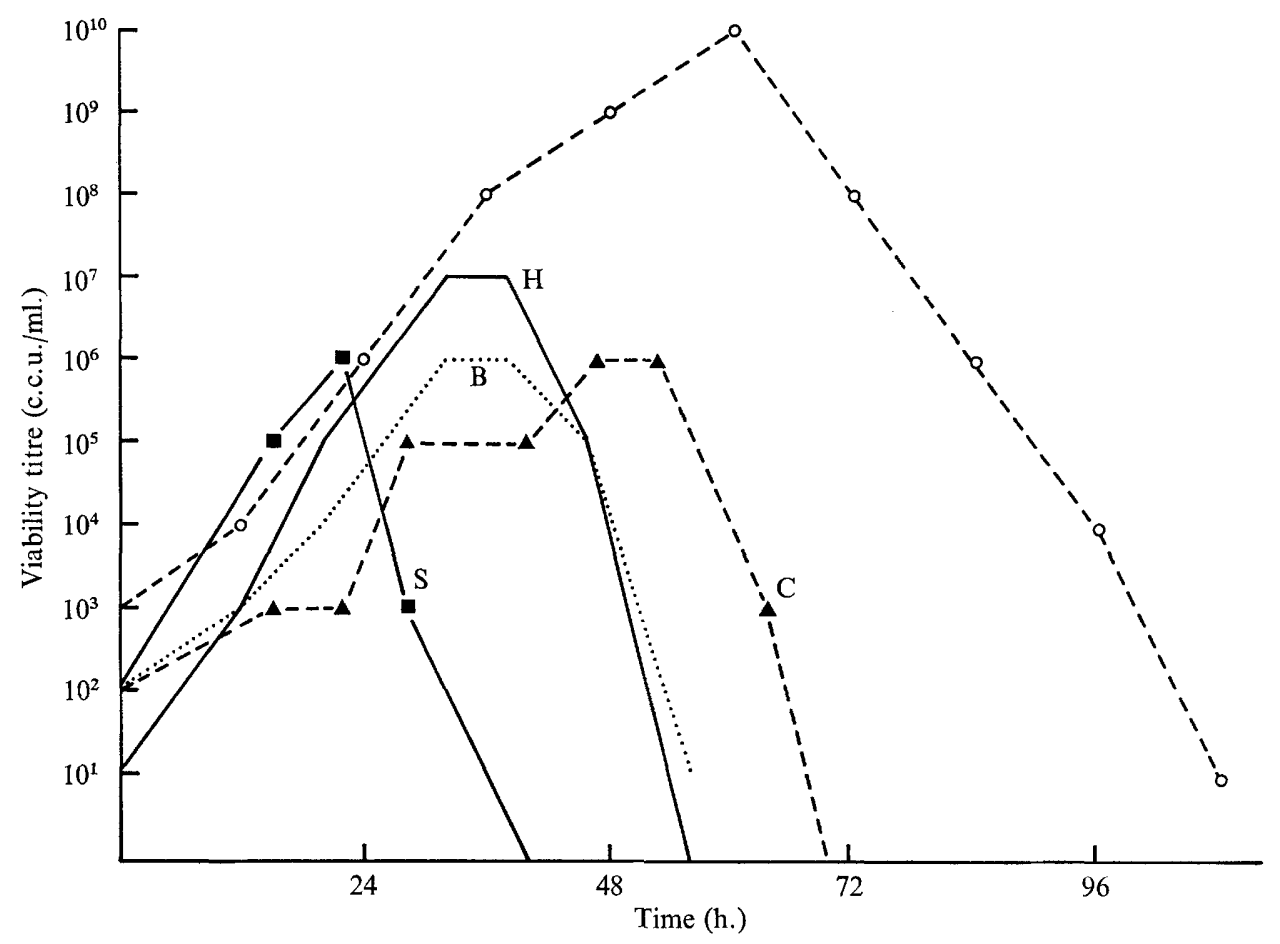

Fig. I. Growth of simian (S), canine (C), bovine (B) and human (H) T-mycoplasmas in liquid medium with $0.1 \%$ urea; growth of Mycoplasma hominis (-- - ) in same medium but with $0.1 \%$ arginine.

There was a rapid increase and an equally rapid decline in the number of viable organisms; the duration of this time (growth cycle) compared with that for $M$. hominis was short (Table 2), that for the simian strain being shortest. In addition, for each strain the maximum number of viable organisms attained was about the same, at least I000-fold less than the maximum number of viable $M$. hominis organisms. The canine and simian strains, like the human and bovine strains, were more susceptible than $M$. hominis to erythromycin, thallium acetate and 5 -bromodeoxyuridine. The canine and simian strains did not metabolize glucose or arginine but they did metabolize urea, with the production of ammonia and a corresponding rapid rise in the $\mathrm{pH}$ of the culture media. It was shown for the simian strain that the addition of 
HEPES buffer resulted in a less rapid rise in $\mathrm{pH}$, an increase in the number of viable organisms, and a consequent increase in the amount of ammonia produced (Table 3). These results were observed previously for a T-mycoplasma of human origin (Manchee \& Taylor-Robinson, $1969 a$ ).

Table 2. Properties of canine and simian T-mycoplasmas compared with those of human and bovine strains and the classical large colony-forming Mycoplasma hominis

\begin{tabular}{|c|c|c|c|c|c|}
\hline \multirow[b]{2}{*}{ Property } & \multicolumn{4}{|c|}{ T-mycoplasma } & \multirow{2}{*}{$\begin{array}{c}\text { Mycoplasma } \\
\text { hominis }\end{array}$} \\
\hline & Canine & Simian & Human & Bovine & \\
\hline \multicolumn{6}{|l|}{ Colony diameter $(\mu \mathrm{m}$.$) :$} \\
\hline $\begin{array}{l}\text { Medium without } \\
\text { HEPES buffer }\end{array}$ & 100 & 70 & 40 & 20 & 200 or $>$ \\
\hline $\begin{array}{l}\text { Medium with HEPES } \\
\text { buffer }\end{array}$ & 230 & 300 & 90 & 80 & 200 or $>$ \\
\hline \multicolumn{6}{|l|}{ Growth in liquid medium: } \\
\hline $\begin{array}{l}\text { Growth cycle* (h. at } \\
37^{\circ} \text { ) }\end{array}$ & 70 & 40 & 56 & 60 & I I 2 \\
\hline $\begin{array}{l}\text { Maximum titre (c.c.u./ } \\
\text { ml.) }\end{array}$ & $10^{6}$ & $10^{6}$ & $10^{7}$ & $10^{6}$ & $10^{10}$ \\
\hline $\begin{array}{l}\text { Time (h.) to attain max. } \\
\text { titre }\end{array}$ & 47 & $15-25$ & 32 & $24-32$ & 60 \\
\hline \multicolumn{6}{|l|}{$\begin{array}{l}\text { Inhibition of growth in } \\
\text { liquid medium by: }\end{array}$} \\
\hline Erythromycin $(\mu \mathrm{g} . / \mathrm{ml})$. & $<30$ & $<30$ & 60 & 30 & $>500$ \\
\hline Thallium acetate $(\%)$ & 0.4 & $0 \cdot 2$ & 0.2 & 0.2 & $>0.8$ \\
\hline $\begin{array}{l}\text { 5-Bromodeoxyuridine } \\
(\mu \mathrm{g} . / \mathrm{ml} .)\end{array}$ & 100 & 100 & 50 & n.t. & $>400$ \\
\hline \multicolumn{6}{|l|}{ Metabolism of: } \\
\hline Glucose & - & - & - & - & - \\
\hline Arginine & - & - & - & - & + \\
\hline Urea & + & + & + & + & - \\
\hline & & $\begin{array}{l}\text { IOO. } \\
\text { Colour-cl } \\
\text { t tested. }\end{array}$ & units. & & \\
\hline
\end{tabular}

Properties similar to those of large colony-forming mycoplasmas. The canine and simian strains were reduced from $10^{6}$ c.c.u. $/ \mathrm{ml}$. to $10^{1}$ c.c.u. $/ \mathrm{ml}$. by ether treatment. On the other hand, 20 cycles of freezing and thawing reduced the titres of viable organisms of each strain by $100-$ fold only and some organisms were preserved by freeze-drying, this process causing a I000-fold reduction in the number of viable organisms. A small proportion of the organisms of each strain, $0.01 \%$ of the canine and $0.0001 \%$ of the simian, passed through Millipore filters of $330 \mathrm{~nm}$. average pore diameter (a.p.d.). Neither strain grew in the absence of horse serum in the medium, and the presence of $0.5 \mu \mathrm{g} . / \mathrm{ml}$. tetracycline inhibited growth of the canine strain and $2.0 \mu \mathrm{g}$. of the drug $/ \mathrm{ml}$. inhibited growth of the simian strain. The multiplication of either strain was not inhibited by 4000 units penicillin $/ \mathrm{ml}$., but growth was inhibited by specific antisera (see Table 5). In these respects, the properties of the T-mycoplasmas were similar to those reported previously for Mycoplasma hominis (TaylorRobinson, Williams \& Haig, 1968).

Cell adsorption to colonies. The larger colonies of T-mycoplasmas on solid medium containing HEPES buffer were examined for their cell adsorptive properties. Erythrocytes of canine, simian, and human species did not absorb to the T-mycoplasma colonies; the 
exception was chicken erythrocytes which adsorbed weakly to colonies of the simian $\mathrm{T}$ mycoplasma (SP I625A). HeLa cells adsorbed to colonies of the T-mycoplasmas of human origin but not to those of other species.

Table 3. Growth of simian T-mycoplasma in liquid medium and production of ammonia Initial $\mathrm{pH}$ of cultures $=6 \cdot 8$; final $\mathrm{pH}$ with HEPES $=7 \cdot 7$; and without HEPES $=8.2$.

Composition of medium

\begin{tabular}{|c|c|c|c|c|}
\hline \multirow{2}{*}{$\begin{array}{l}\text { Time of } \\
\text { incubation } \\
\text { (h. at } 36^{\circ} \text { ) }\end{array}$} & \multicolumn{2}{|c|}{$0.1 \%$ Urea; no HEPES buffer } & \multicolumn{2}{|c|}{$0.1 \%$ Urea and $0.05 \mathrm{M}$-HEPES buffer } \\
\hline & $\begin{array}{c}\text { Growth } \\
\text { (c.f.u. } / \mathrm{ml} \text { ) }\end{array}$ & $\begin{array}{l}\text { Ammonia } \\
(\mu \mathrm{g} . / \mathrm{ml} .)\end{array}$ & $\begin{array}{c}\text { Growth } \\
\text { (c.f.u. } / \mathrm{ml} \text { ) }\end{array}$ & $\begin{array}{c}\text { Ammonia } \\
(\mu \mathrm{g} . / \mathrm{ml} .)\end{array}$ \\
\hline 0 & $2.0 \times 10^{1}$ & 0 & $2.0 \times 10^{1}$ & 0 \\
\hline 12 & $\mathrm{I} \cdot 2 \times 10^{3}$ & 9 & $7 \cdot 4 \times 10^{3}$ & 60 \\
\hline 16 & $2.0 \times 10^{3}$ & 34 & $2 \cdot 2 \times 10^{5}$ & 298 \\
\hline 24 & $\mathrm{I} \cdot \mathrm{O} \times 1 \mathrm{I}^{4}$ & 264 & $\mathrm{I} \cdot \mathrm{O} \times 10^{4}$ & 400 \\
\hline 36 & 0 & 314 & 0 & 630 \\
\hline 48 & 0 & 400 & 0 & 630 \\
\hline
\end{tabular}

Table 4. Serological relationship of some large colony-forming mycoplasmas to T-mycoplasmas

Antisera to large
colony-forming
mycoplasmas
Human strains
$M$. salivarium
$M$. orale 1
$M$. orale 2
$M$. hominis
$M$. fermentans
$M$. pneumoniae
Bovine strains
$M$. mycoides
$M$. bovigenit.
$M$. laidlawii
D I2
DONETTA
$5 \mathrm{M} 33$ I
N 29
SQUIRE
Canine strains
$M$. canis
$M$. spumans
$M$. maculosum

* REOW and JOHNSON.
Metabolic inhibition titre against

\begin{tabular}{|c|c|c|c|c|}
\hline $\begin{array}{l}\text { Homologous } \\
\text { mycoplasma }\end{array}$ & $\underset{T}{\text { Human }}$ & $\underset{T}{\operatorname{Simian}}$ & $\begin{array}{c}\text { Bovine } \dagger \\
\mathrm{T}\end{array}$ & $\underset{T}{\text { Canine }}$ \\
\hline 10,240 & $<20$ & $<20$ & \multirow{6}{*}{ n.t. } & \multirow{6}{*}{ n.t. } \\
\hline 2,560 & $<20$ & $<20$ & & \\
\hline $5, \mathrm{I} 20$ & $<20$ & $<20$ & & \\
\hline 2,560 & $<20$ & $<20$ & & \\
\hline 2,560 & $<20$ & $<20$ & & \\
\hline 640 & $<20$ & $<20$ & & \\
\hline 40 & \multirow{8}{*}{ n.t. } & \multirow{8}{*}{ n.t. } & $<20$ & \multirow{8}{*}{ n.t. } \\
\hline 320 & & & 20 & \\
\hline 160 & & & $<20$ & \\
\hline $5, \mathrm{I} 20$ & & & 20 & \\
\hline 10,240 & & & 20 & \\
\hline 20,480 & & & $<20$ & \\
\hline 320 & & & $<20$ & \\
\hline 320 & & & $<20$ & \\
\hline 640 & \multirow{3}{*}{ n.t. } & \multirow{3}{*}{ n.t. } & \multirow{3}{*}{ n.t. } & $<20$ \\
\hline 320 & & & & $<20$ \\
\hline 320 & & & & $<20$ \\
\hline
\end{tabular}

\section{Antigenic relationships}

Serological relationships to some large colony-forming mycoplasmas. As shown in Table 4, antisera to six large colony-forming mycoplasmas of human origin were tested by the metabolic inhibition (m.i.) technique against the T-mycoplasmas of human and simian origin. No inhibition was detected at antiserum dilutions of $1: 20$. Similarly, antisera to eight large colony-forming mycoplasmas of bovine origin were tested against the T-mycoplasmas of bovine origin. In only three instances was inhibition detected at antiserum 
dilutions of $\mathrm{I}: 20$. Finally, antisera to three large colony-forming mycoplasmas of canine origin were tested against the T-mycoplasma of canine origin. No inhibition was detected at dilutions of $1: 20$.

In addition, antisera to the T-mycoplasmas (homologous titres shown in Table 5) were tested against the large colony-forming mycoplasmas isolated from the same host species as the T-mycoplasmas. Inhibition did not occur at the lowest dilution of the antisera tested, namely $\mathrm{I}: 20$.

Table 5. Serological relationships between T-mycoplasmas

\begin{tabular}{|c|c|c|c|c|c|c|c|}
\hline \multirow[b]{2}{*}{ T-mycoplasma } & \multicolumn{7}{|c|}{ Metabolic inhibition titre with antisera to } \\
\hline & REOW & JOHNSON & $\mathrm{T} 354$ & u 8 & U I4 & SP I 625A & SP I 701 \\
\hline REOW & 1280 or $>$ & n.t. & n.t. & $<20$ & $<20$ & $<20$ & $<20$ \\
\hline JOHNSON & 20 & 640 & $<20$ & 40 & 40 & $<20$ & $<20$ \\
\hline Т 354 & 80 & 20 & 320 & 40 & 40 & $<20$ & $<20$ \\
\hline u 8 & 20 & 20 & $<20$ & 1280 & 40 & $<20$ & $<20$ \\
\hline U I4 & $<20$ & 20 & $<20$ & $<20$ & 640 & $<20$ & $<20$ \\
\hline SP $1625 \mathrm{~A}$ & $<20$ & $<20$ & $<20$ & $<20$ & $<20$ & 640 & $<20$ \\
\hline SP I 701 & $<20$ & $<20$ & 20 & $<20$ & 20 & $<20$ & 2560 \\
\hline
\end{tabular}

Serological relationships between T-mycoplasma strains isolated from a particular animal species. The results of previous studies (Purcell et al. 1967; Ford, 1967) showed that several strains isolated from man were not identical. Likewise, bovine strains U 8 and U I 4 were distinct from each other when examined by the m.i. technique (Table 5). Furthermore, while antiserum to the canine strain SP I 7OI inhibited the metabolism of the homologous organism when diluted $\mathrm{I}: 2560$, it did not inhibit at a dilution of $\mathrm{I}: 20$ the metabolism of the other two canine strains isolated. It seems, therefore, that at least two antigenically distinct strains of canine T-mycoplasmas exist. On the other hand, antiserum to the simian strain SPI625A inhibited the homologous strain when diluted $\mathrm{I}: 640$ and it inhibited the four other strains isolated at about the same dilution, indicating the close relationship of the simian strains to each other.

Serological relationships between T-mycoplasma strains isolated from different animal species. Antisera to various T-mycoplasma strains were tested by the m.i. technique against the homologous strains and against T-mycoplasmas from other animal species (Table 5). Strains isolated from one species were not antigenically identical to those isolated from another species.

Polyacrylamide gel electrophoresis. At least one strain of T-mycoplasma from each animal species was grown in the same medium and all of them were examined by the electrophoresis technique at the same time. At least I I distinct protein bands were visible to the naked eye; these bands were recorded better by photography or by drawing (Fig. 2) than by densitometer tracing. The patterns for the two human T-mycoplasmas REOW and JOHNSON and for the bovine T-mycoplasma u 8 were very similar. Those for the simian and canine strains appeared similar to each other and were probably little different from the human and bovine, the main difference being one of band density. The pattern observed for any of the T-mycoplasmas was strikingly different from patterns we have obtained with other mycoplasmas, e.g. Mycoplasma gallisepticum (Fig. 2). Thus, although the results of the m.i. tests indicated marked differences between the T-mycoplasma strains, the patterns of protein bands observed in the polyacrylamide gels suggested that the various strains had many structural components in common. 


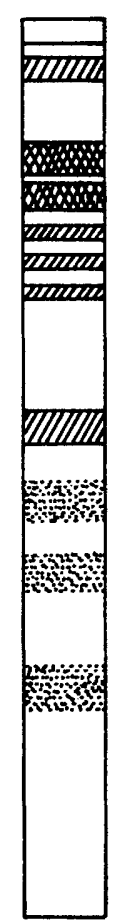

(a)

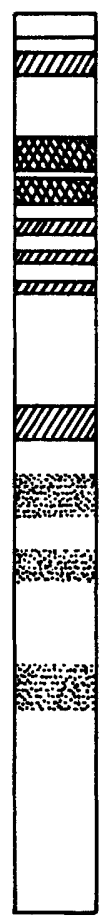

(b)

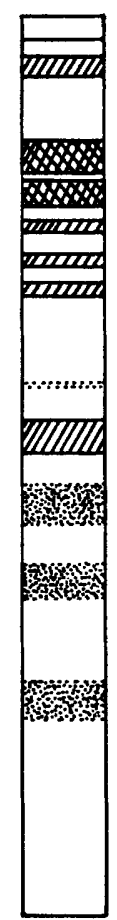

(c)

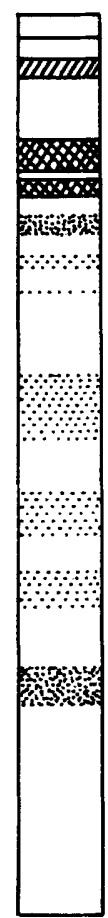

(d)

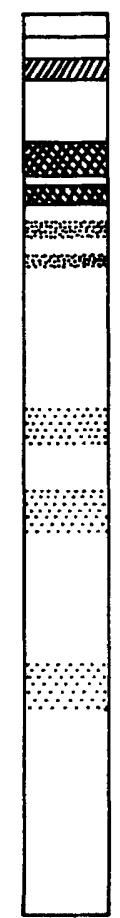

(e)

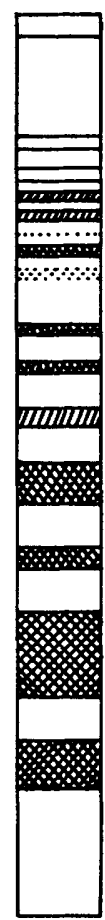

$(f)$

Fig. 2. Polyacrylamide gel electrophoresis patterns of proteins of (a) bovine T-mycoplasma U 8 , (b) human T-mycoplasma REOw, (c) human T-mycoplasma JOHNSON, (d) simian T-mycoplasma SP I625 A, (e) canine T-mycoplasma SP I70I, $(f)$ Mycoplasma gallisepticum (s6).

\section{DISCUSSION}

In this study T-mycoplasmas were isolated only from dogs and squirrel monkeys, although a variety of other species was examined. Our failure to isolate from other species could be due to the absence of $\mathrm{T}$-mycoplasmas from these species or to the organisms having different growth requirements, or to insufficient sampling. However, the relative ease with which we have been able to isolate T-mycoplasmas from a particular species, e.g. cattle, their repeated isolation from one animal, and the finding of a large number of organisms in a specimen, suggest to us that our failure to isolate these organisms from other species is probably due to their infrequent occurrence or absence. Organisms isolated previously from cattle (TaylorRobinson, Williams \& Haig, 1968) were not considered to be bacteria in their L-phase because isolations were made without antibiotics in the medium. However, there were no differences between organisms isolated in the absence or presence of antibiotics. In view of this, in the present study we did not attempt to isolate without antibiotics particularly because we knew from previous experience that this would be difficult. The results obtained, as discussed below, suggest that our approach to isolation using antibiotics was justified.

Previously we showed (Taylor-Robinson, Williams \& Haig, I968) that the characteristics of bovine strains were similar to those of human T-mycoplasmas as outlined by Shepard ( $1967 ; 1969)$, so that the bovine organisms could indeed be regarded as T-mycoplasmas. In the present study, it has not been possible to demonstrate more than minor biological 
differences between strains isolated from the various species. As examples of such differences, the size of canine T-mycoplasma colonies was greater and the rate of multiplication of simian organisms was faster than that of strains isolated from other species. We have made no reference in this communication to haemolysis by T-mycoplasmas, but this property has been examined in detail before (Manchee \& Taylor-Robinson, 1970). Alpha (prime)-type haemolysis was demonstrated more easily with some strains than it was with others, but in this respect the differences between strains were again small. Thus, because we have shown the biological characteristics of the canine T-mycoplasma to be similar to those of the simian and, indeed, similar to those of the human and bovine strains, we have no hesitation in regarding the canine and simian strains as being members of the T-mycoplasma group.

The usual course of action, as recommended by the Subcommittee on the Taxonomy of Mycoplasmatales (Edward et al. 1967), is to establish that a newly isolated strain is also different serologically from all other known mycoplasmas before regarding it as unique. However, because of the unique biological features of the T-mycoplasma group of organisms, in particular the metabolism of urea, it was clearly not necessary to test these strains against antisera prepared against all the large colony-forming mycoplasmas known to exist in order to demonstrate a lack of relationship with the latter. It seemed to us sufficient to examine the relationship between the large colony-forming mycoplasmas of an animal species and the T-mycoplasmas isolated from that species. To our knowledge, no large colony-forming mycoplasmas of squirrel monkeys have been described. However, the large colony-forming mycoplasmas of African green monkeys are similar to those of man (DelGiudice, Carski, Barile, Yamashiroya \& Verna, 1969) and so we examined the relationship between the latter mycoplasmas and a T-mycoplasma isolated from a squirrel monkey. Where examinations of this sort were made, no serological relationships were shown. Having established that the T-mycoplasmas were not serologically related to other mycoplasmas it was important to determine the serological relationship between $\mathrm{T}$-mycoplasmas isolated from one species and those isolated from another. Attempts were made to do this by several different approaches. Cell adsorption in previous (Manchee \& Taylor-Robinson, I969a) and present work was not observed to occur with all strains tested and the inhibition of adsorption by antisera was insufficiently reproducible to be of value. Likewise, the same antisera placed in filter-paper discs did not prevent the development of colonies on agar medium. Although this growth-inhibition test on solid medium was unsuccessful, the m.i. test in liquid medium was sufficiently sensitive and reproducible, as shown previously for human strains (Ford, I967; Purcell et al. 1966). By this test the strains isolated from one animal species were distinct from those isolated from another. These differences were no greater, however, than the differences detected between a number of T-mycoplasma strains isolated from a particular animal species. On the other hand, the results of the polyacrylamide gel electrophoresis studies indicated that the structural components of strains isolated from various animal species were closely similar, only minor differences being detected, so that all strains could be regarded as falling into one closely related group. The fact that the results of the m.i. test indicated wide antigenic differences between strains is probably a reflection of its sensitivity and specificity, particularly with rabbit antisera (Taylor-Robinson et al. 1966). The differences noted are probably due to differences in the antigenic composition of the membranes, since antibody measurable by the m.i. technique is known to react with sites on the membrane (Williams \& Taylor-Robinson, 1967). It seems to us that when nomenclature is to be considered, emphasis should be placed on the similarity of strains and that a name referable to the group as a whole should be used. As suggested before (Manchee \& Taylor-Robinson, 1969a), one based on the metabolism of urea would seem most appro- 
priate. If this were to be done, reference to strains isolated from a particular animal species could be made by indicating the species in question, e.g. var. hominis, var. bovis, etc.

The authors thank the following persons who supplied specimens or helped in obtaining them: Dr P. J. Chapple, Mr P. L. Dawson, Dr Ten Feizi, Mr R. Henry, Dr R. J. Manchee, Mr H. V. Thompson and Dr J. D. Treharne. We thank also Mrs S. Beveridge, Miss N. G. Frost and Mrs K. A. Keast for excellent technical assistance.

C.M.-B., visiting worker from Centro Nacional de Virologia y Ecologia Sanitarias, Madrid, Spain, was supported by a W.H.O. Fellowship.

T.W., visiting worker from Department of Oral Microbiology, Tokyo Medical and Dental University, Tokyo, Japan, was supported by a British Council Fellowship.

\section{REFERENCES}

Delgiudice, R. A., Carski, T. R., Barile, M. F., Yamashiroya, H. M. \& Verna, J. E. (i969). Recovery of human mycoplasmas from simian tissues. Nature, London 222, 1088-1089.

Edward, D. G. fF., Freundt, E. A., Chanock, R. M., Fabricant, J., Hayflick, L., Lemcke, R. M., Razin, S., Somerson, N. L. \& Wittler, R. G. (I967). Recommendations on nomenclature of the order Mycoplasmatales. Science, New York r55, 1694-I 696.

FoRD, D. K. (1967). Relationships between mycoplasma and the etiology of nongonococcal urethritis and Reiter's syndrome. Annals of the New York Academy of Sciences 143, 501-504.

Gourlay, R. N. (1968). The isolation of T-strains of Mycoplasma from pneumonic calf lungs. Research in Veterinary Science 9, 376-378.

Lowry, O. H., Rosebrough, N. J., Farr, A. L. \& Randall, R. J. (I95I). Protein measurement with the Folin phenol reagent. Journal of Biological Chemistry 193, 265-275.

MANCHEE, R. J. \& TAYLOR-RoBINSON, D. (1968). Haemadsorption and haemagglutination by mycoplasmas. Journal of General Microbiology 50, 465-478.

MANChEe, R. J. \& TAYLOR-Robinson, D. (1969a). Enhanced growth of T-strain mycoplasmas with N-2hydroxyethylpiperazine- $N^{\prime}$-2-ethanesulfonic acid buffer. Journal of Bacteriology 100, 78-85.

MANCheE, R. J. \& TAYLOR-Robinson, D. (1969 $b$ ). Studies on the nature of receptors involved in attachment of tissue culture cells to mycoplasmas. British Journal of Experimental Pathology 50, 66-75.

MANCheE, R. J. \& TAYloR-Robinson, D. (I970). Lysis and protection of erythrocytes by T-mycoplasmas. Journal of Medical Microbiology 3, 539-546.

Purcell, R. H., Taylor-Robinson, D., Wong, D. \& Chanock, R. M. (i966). Colour test for the measurement of antibody to T-strain mycoplasmas. Journal of Bacteriology 92, 6-I 2.

Purcell, R. H., Wong, D., Chanock, R. M., Taylor-Robinson, D., Canchola, J. \& Valdesuso, J. (i967). Significance of antibody to mycoplasma as measured by metabolic-inhibition techniques. Annals of the New York Academy of Sciences 143, 664-675.

RAZIN, S. \& RoTTEM, S. (I967). Identification of Mycoplasma and other micro-organisms by polyacrylamidegel electrophoresis of cell proteins. Journal of Bacteriology 94, 1807-1 8I0.

SHEPARD, M. C. (I954). The recovery of pleuropneumonia-like organisms from Negro men with and without nongonococcal urethritis. American Journal of Syphilis, Gonorrhea and Venereal Diseases 38, I I3-I 24.

SHEPARD, M. C. ( 1967 ). Cultivation and properties of T-strains of mycoplasma associated with nongonococcal urethritis. Annals of the New York Academy of Sciences 143, 505-5I4.

ShePard, M. C. (1969). Fundamental biology of the T-strains. In Mycoplasmatales and the L-phase of Bacteria, p. 49-65. Edited by L. Hayflick. New York: Appleton-Century-Crofts.

TAYLOR-RoBInSON, D. (I967). Mycoplasmas of various hosts and their antibiotic sensitivities. Postgraduate Medical Journal 43, Suppl. I00-IO4.

Taylor-Robinson, D., Addey, J. P., Hare, M. J. \& Dunlop, E. M. C. (1969). Mycoplasmas and 'nonspecific' genital infection. I. Previous studies and laboratory aspects. British Journal of Venereal Diseases 45, 265-273.

TAylor-Robinson, D., HAig, D. A. \& Williams, M. H. (1967). Bovine T-strain mycoplasma. Annals of the New York Academy of Sciences, 143, 517-518. 
TAYLOR-Robinson, D. \& PuRcell, R. H. (1966). Mycoplasmas of the human urogenital tract and oropharynx and their possible role in disease: a review with some recent observations. Proceedings of the Royal Society of Medicine 59, I I I 2-I I 16.

Taylor-Robinson, D., Purcell, R. H., Wong, D. C. \& Chanock, R. M. (1966). A colour test for the measurement of antibody to certain mycoplasma species based upon the inhibition of acid production. Journal of Hygiene 64, 91-104.

Taylor-Robinson, D., Somerson, N. L., Turner, H. C. \& Chanock, R. M. (I963). Serological relationships among human mycoplasmas as shown by complement-fixation and gel diffusion. Journal of Bacteriology $85,126 I-I 273$.

Taylor-Robinson, D., Thomas, M. \& Dawson, P. L. (1969). The isolation of T-mycoplasmas from the urogenital tract of bulls. Journal of Medical Microbiology 2, 527-533.

TaYlor-Robinson, D., Williams, M. H. \& HaiG, D. A. (I968). The isolation and comparative biological and physical characteristics of T-mycoplasmas of cattle. Journal of General Microbiology 54, 33-46.

Williams, M. H. \& TAYLOR-RobINSON, D. (1967). Antigenicity of mycoplasma membranes. Nature, London 215, 973-974. 